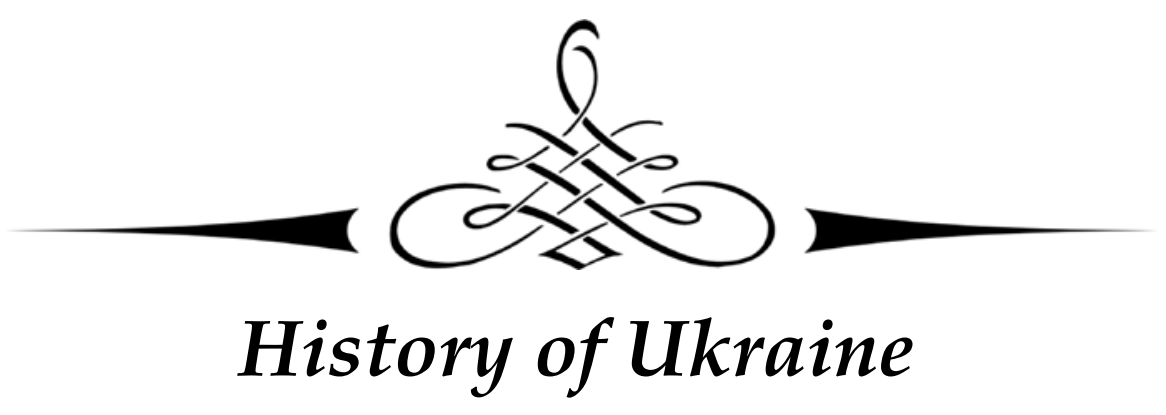

удк: 94:314-053.2(477.53) «1648/1790»

DOI: 10.26661/zhv-2019-1-53-01

\title{
Infant mortality in the population of the Cossack Ukraine in the second half of the XVIII-th century
}

\author{
I. Serdiuk \\ Poltava V.G. Korolenko National Pedagogical University \\ ig.serdiuk@gmail.com
}

Key words: Hetmanschyna, childhood, history, mortality, historical demography.

The article considers child mortality of the Hetmanschyna population of the XVIII-th century. The primary source of research is the Church metrical book of the Nativity of Christ found at the small town Yaresky of Myrhorodskyi regiment. With the application of historical and demographic methods and approaches, the basic mortality rate and its features are determined. It was revealed that in the Hetmanschyna only the postnatal infant's mortality rate was recorded, but neonatal mortality was almost not taken into account. Even considering such a misreporting, children between the ages of 0-14 constituted a part of more than half of all the dead ones recorded in metric books. This fact corresponded to the «paradox of infant mortality», according to which, the mortality rate declined sharply with each passing year until reaching the age of 5 years. Actually totally 460 children out of the thousand baptized infant survived and reached 5 years of age. The highest mortality rate was in the first years of life, but the exact life duration determination is excluded and become impossible by the fact that when recording the age of all children at the age of several days, weeks or months were recorded as those who were one year old. Thus, under this marker, two one-year age groups are accrued. This makes impossible to calculate accurately the infant mortality rate.

The obtained demographic indicators evidenced that infant mortality had a strongly pronounced seasonal prevalence. April was the most dangerous month for children, which was explained by communicable diseases burst. In addition, in April, the challenges with food commenced, and malnutrition weakened the body's resistance. In the first instance, it concerned children who had not been breastfed anymore. On the other hand, famine weakened the mothers who were giving birth at that time. During heavy yield summer months, the infant mortality raised again from June to August. This month is the second highest by mortality rate in Yaresky. The warm year season traditionally contributed to diseases of the digestive tract, food poisoning, intestinal infections. The August's peak of mortality can be explained by the deterioration of drinking water quality, as well as the engagement in the fieldwork, which affected and worsened childcare. Autumn's mortality outbreak was caused by infectious diseases, which rapidly spread due to the microclimate of the living space. In general, such mortality was inherent in an agrarian, traditional society that was not introduced to professional medicine and health care. 


\section{Дитяча смертність в населенні козацької України другої половини XVIII ст.}

\section{0. Сердюк \\ Полтавський національний педагогічний університет імені В.Г.Короленка}

Ключові слова: Гетьманщина, дитинство, історія, смертність, історична демографія.

\begin{abstract}
У статті вивчається дитяча смертність в населенні Гетьманщини XVIII ст. Основним джерелом дослідження $є$ частина про «померлих» метричних книг церкви Різдва Христового містечка Яреськи Миргородського полку. За допомогою історико-демографічних методик встановлено основні коефіцієнти смертності, її характеристики. На основі даних коефіцієнтів висловлено припущення про основні причини смертності, чинники, що впливали на їі коливання. Встановлено, що дитяча смертність мала яскраво виражену сезонність, що визначалася особливостями клімату, температурними коливаннями, забезпеченістю їжею та питною водою, спалахами інфекційних хвороб та мікрокліматом житлового простору. Загалом така смертність була притаманною аграрному традиційному суспільству, що не знало професійної медицини та медико-санітарного догляду.
\end{abstract}

The theme of death is not something unexpected in European historiography, and even a kind of "boom" of similar studies in the 70's and 80's of the XX-th century made French historian Michel Vovelle warn against mixing the research of death with fashion. Calls of Vovelle concerned primarily medievalists and modernists who most actively discussed the problem of historical anthropology in general, and death in particular. Their interest is not accidental - that is in the era of dominance of religious consciousness that people's attention was focused on death, death court, paradise and hell. As aptly mentioned well known medievalist Aron Gurevich, "death was a major component of culture, a "screen", on which all the values of life were projected." [1, p. 6-9].

The comments by Michel Vovelle can hardly seriously relate to Ukrainian historiography, though, because his famous book so far has not been translated into Ukrainian yet [2]. Maybe it is the absence of such translations that resulted in the fact that the theme of death in Ukraine is represented mainly by research in necropolistic and by rare historical and demographic studies. Moreover, the only comprehensive study (at the level of a book) by Olena Zamura is perceived by colleagues partly as something extravagant and exotic [3]. Specifically it is one of those topics on the materials of Ukraine where the matter is not so much in filling gaps but more in the development of a large untouched space. Infant mortality is more researched on materials of Central and Western Europe $[4,5,6,7]$.

Personally I am interested in a piece of that space as the problem of infant mortality in Hetmanschyna of the XVIII-th century, the study of which opens the way to understanding the perception of the child in Ukrainian traditional society of that time $[8,9,10,11]$. The components of this problem are the questions: causes and mechanisms of mortality, child care, children's death experiences of their parents, the attitude towards children's bodies, especially the burial, the idea of the fate of the soul of the child in the "afterlife" world and so on. In the same research I'll try to focus on the study of individual demographic parameters of infant mortality in Hetman State as:

- Mortality and natural increase in population;

- Age-related aspects of child mortality;

- Seasonal and annual variations in mortality;

- The main causes of death.

"The scene» and features source research.

I consider it necessary to describe briefly "the scene". It is Yaresky - squadron town of Myrhorod Regiment. It is a typical small town in central Hetman State considering the number of inhabitants and their occupations, economic development and other specifics. It is located away from major roads, had developed industry, it was not significant in the span of migration and avoided major outbreaks of epidemic diseases such as plague, which swept the region in 1771. Therefore Yaresky population can be considered in terms of a closed pre-industrial agrarian society and we can clearer trace mechanisms of its existence as a biological population.

The main source of research is the metric book of the Church of the Nativity, whose ward were residents of the town Yaresky. In the proposed period the church belonged to Sorochyn protopope parish of Diocese of Kyiv, and from 1777 it moved to Pereyaslav-Boryspil Diocese. Parishioners of the 
church were both simple inhabitants and nobility of the town.

The document is localized in the fund №1011 of State Archives of Poltava region. The book is very well preserved, written in cursive of the XVIII-th century, which is easy to read and consists of three parts each of which recorded the baptism of children, marriage and death, respectively. Last entries of books date back to $1755-1775$ years, but records of 1775 are unfinished, fixing of baptisms starts from 1757, and not even from the first days of the year. Therefore, this study is confined by the years 1758-1774 [12].

Our source is the typical "representative" of Hetman State Orthodox metrics with all their features and drawbacks. They are a set of acts of church registration demonstrating baptism events (birth), wedding (marriage), burial (death) of specific individuals in the form of chronological records. Directly in the Hetman State they were introduced in 1722 and 1724, but by the end of the eighteenth century the government was not able to force priests to take notes in accordance with the optimal model. Therefore, in these parish registers the date of birth of the child isn't mentioned, but only its baptism is. Accordingly, only baptized were accounted in case of death, and the reason of it was not indicated [13, p. 36-50].
Due to the low level of education and the irresponsible attitude of priests, the books were full of errors, inaccuracies in the sense of specifying names, ages, dates etc. This is particularly evident in rounding age of deceased, that include many “jubilee people". The last phenomenon enables verification of the source for accuracy and comparing it to other similar documents. The most established tool for this is the so-called Whipple index. It is used to determine the degree of precision of the source, depending on the prevalence jubilee men there, and is determined by a special formula:

$$
I={\frac{\sum_{62}^{23} P a, \text { ending on } \mathbf{0} \text { i } \mathbf{5}}{\frac{\mathbf{1}}{\mathbf{5}} \times \sum_{\mathbf{6 2}}^{\mathbf{2 3}} P a}}_{\times 100}
$$

where: I - Whipple index, $\mathrm{Pa}$ - the number of population [14, p. 204-205].

Substituting in this formula the data from registry books of the Church of the Nativity, we get the index of 124.4. According to the established scale, the index below 125 means good quality of the accounting sources and deviation from accurate data less than $25 \%$ (see. Table 1 ).

Table 1. Standards of the UNO for measuring Whipple index.

\begin{tabular}{|c|c|c|}
\hline Whipple index & Data quality & Deviation from the ideal \\
\hline$<$ & very accurate & $<$ \\
\hline $105-110$ & relatively accurate] good & $5-9,99 \%$ \\
$110-125$ & bad & $10-24,99 \%$ \\
\hline $125-175$ & very bad & $25-74,99 \%$ \\
$<$ & & $\geq 75 \%$ \\
\hline
\end{tabular}

Such figure indicates that the metric book was much more accurate than the source materials of fiscal accounting. For example, the classic source of civil (fiscal) account, as General description of Poltava in 1766 has Whipple index at 360, and is characterized with extremely low accuracy. The accuracy of "our" sources is more comparable with other documents of church records, such as confession paintings, which Whipple index for Poltava parishes of the XVIII-th century is from 107 to 170 [15, p. 1-8].

Finally, I'll mention another bug whole of church population accounting documentation of Hetman State - its fragmentation. Very many church documents were destroyed by the Communists in the 20 's and 30's of the XX-th century during the anti-religious campaigns. Therefore, according to Ukrainian historian Vitaly Dmytrenko, only 441 metric book were preserved from the hundred fif- teen towns, which were squadron and regimental centers of Hetman State in the XVIII century. And 103 of them are related to the first half of the XVIIIth century, and the remaining 338 present its second part [13, p. 32-33]. Such fragmentation makes it impossible to study the infant mortality in the long chronological intervals at this stage, as it has done recently, for example, Polish historian Mateusz Wyżgana on the materials of one of the parishes of the Commonwealth of Poland [4, p. 161-185].

Natural increase and basic parameters of mortality.

Firstly, let's briefly describe the structure of mortality and its main demographic indicators. 0verall there were 636 baptisms of infants and 533 recorded deaths in Yaresky in 1758-1774's (see. Table. 2).

As we can see, the absolute natural increase was positive and noticeable for such a small settlement 
which population grew to 103 persons in 17 years. In most years the birth rate exceeded the mortality in the town, the year 1763 was especially favorable in this respect, when the difference between the rates was more than two times. Mortality was four times higher during the 17-year period $(1762,1767$, $1771,1773)$ [12]. Significantly, the high value of negative natural increase was in 1771 - during the year of the plague spread on the territory of Ukraine. However, does it confirm my assumption in the beginning of this article that the epidemic party passed Yaresky by? I think, no, because, as can be seen from Table 2, not far more people died in a town that year than in the most affluent in demographic terms years, including 1763 [12]. The main reason for the demographic crisis was a sharp decline in the number of baptized children. It could be caused by a decline in fertility and mortality rise among newborns who just did not live up to the baptism. One reason for this could be a plague of course, however, the assumptions in this regard will be to express a little later.

Table 2. Absolute numbers of Natural increase of population of town of Yaresky in the 1758-1774 biennium. (B - baptized, D - died, I - increase).

\begin{tabular}{|c|c|c|c|c|c|c|c|c|c|}
\hline \multirow{2}{*}{ Year } & \multicolumn{4}{|c|}{ Men } & \multicolumn{3}{c|}{ Women } & \multicolumn{3}{|c|}{ Total } \\
\cline { 2 - 10 } & B & D & I & B & D & I & B & D & I \\
\hline 1758 & 23 & 12 & 11 & 17 & 13 & 4 & 40 & 25 & 15 \\
\hline 1759 & 23 & 16 & 7 & 16 & 11 & 5 & 39 & 27 & 12 \\
\hline 1760 & 22 & 14 & 8 & 21 & 23 & -2 & 43 & 37 & 6 \\
\hline 1761 & 16 & 14 & 2 & 13 & 14 & -1 & 29 & 28 & 1 \\
\hline 1762 & 23 & 25 & -2 & 24 & 29 & -5 & 47 & 54 & -7 \\
\hline 1763 & 24 & 15 & 9 & 34 & 11 & 23 & 58 & 26 & 32 \\
\hline 1764 & 19 & 17 & 2 & 21 & 17 & 4 & 40 & 34 & 6 \\
\hline 1765 & 24 & 21 & 3 & 24 & 25 & -1 & 48 & 46 & 2 \\
\hline 1766 & 19 & 11 & 8 & 20 & 15 & 5 & 39 & 26 & 13 \\
\hline 1767 & 17 & 23 & -6 & 17 & 22 & -5 & 34 & $\mathbf{4 5}$ & -11 \\
\hline 1768 & 27 & 16 & 11 & 20 & 27 & -7 & 47 & $\mathbf{4 3}$ & 4 \\
\hline 1769 & 22 & 15 & 7 & 10 & 7 & 3 & 32 & $\mathbf{2 2}$ & 10 \\
\hline 1770 & 10 & 9 & 1 & 15 & 8 & 7 & 25 & $\mathbf{1 7}$ & 8 \\
\hline 1771 & 14 & 18 & -4 & 9 & 13 & -4 & 23 & $\mathbf{3 1}$ & -8 \\
\hline 1772 & 12 & 10 & 2 & 11 & 10 & 1 & 23 & $\mathbf{2 0}$ & 3 \\
\hline 1773 & 14 & 21 & -7 & 15 & 13 & 2 & 29 & $\mathbf{3 4}$ & -5 \\
\hline 1774 & 21 & 9 & 12 & 19 & 9 & 10 & 40 & $\mathbf{1 8}$ & 22 \\
\hline Total & $\mathbf{3 3 0}$ & $\mathbf{2 6 6}$ & $\mathbf{6 4}$ & $\mathbf{3 0 6}$ & $\mathbf{2 6 7}$ & $\mathbf{3 9}$ & $\mathbf{6 3 6}$ & $\mathbf{5 3 3}$ & $\mathbf{1 0 3}$ \\
\hline
\end{tabular}

What to absolute numbers in their sexual perspective, somehow surprising is the fact that the natural growth of the female population was almost twice lower than that of men. Although it is traditionally considered that in the closed agrarian society it should rather be conversely, corresponding sex ratio at birth. There is a concept of "the secondary sex ratio" in demographic science which is a biological constant and equals to 105-106 births of boys per 100 births of girls [16, p. 62]. Researchers tend to explain less sex ratio of children with the higher mortality rates among boys [17, p. 28-29] and, secondly, with underestimation of girls. According to estimates, 107-108 boys were baptized for every 100 girls in Yaresky in 1758-1774.

Absolute numbers do not allow comparison with the data of other researchers, so I'll try to calculate relative ones wherever possible. They represent the ratio of demographic events to the population and are calculated on the same basis. For example, the overall mortality rate is traditionally calculated as follows:

$$
m=\frac{}{\mathrm{PX}_{\mathrm{T}}} \times 10
$$

where: $\mathrm{m}$ - mortality rate;

$\mathrm{N}$ - number of deaths;

$\mathrm{P}$ - the average population for the period of time;

$T$ - the time period for which you want to calculate the ratio [16, p. 92].

Fertility rate is calculated in the same pattern. Our source gives a direct indication of the number of births/deaths in some years or together. We have only to find the number of Yaresky inhabitants in the underlying period. Unfortunately, Materials of 
General description of the town are not reached so far, confession books of that time are not available as well. So we will use data description of Kiev province of 1775-1787, where 1108 persons of both sexes lived in 1786 [18, p. 278]. This number needs some correction, since for time to describe the number of Yaresky residents had to change (increase). I calculated above that town population increased by 103 persons on average 6 per year in 1758-1774 years. Assuming that these growth rates were kept to 1787 , the settlement had 1036 inhabitants to 1775 than. Therefore, based on this number and using appropriate data of registry books (the difference between births and deaths) we can set the population of the town in some years. This, in turn, will help to calculate the fluctuations of fertility / mortality in some years and define common to all examined period. The results of these calculations are presented in Table 3.

Table 3. Vital ratios of town of Yaresky in the 1758-1774 biennium (\%o).

\begin{tabular}{|c|c|c|c|c|}
\hline Year & Population & birth coefficient & $\begin{array}{c}\text { mortality } \\
\text { coefficient }\end{array}$ & $\begin{array}{c}\text { natural increase } \\
\text { coefficient }\end{array}$ \\
\hline 1758 & 958 & $41,8 \%$ o & $25,6 \%$ & $16,2 \%$ \\
\hline 1759 & 970 & $40,2 \%$ & $27,8 \%$ & $12,4 \%$ \\
\hline 1760 & 976 & $44,1 \%$ & $37,9 \%$ & $6,2 \%$ \\
\hline 1761 & 977 & $29,7 \%$ o & $28,7 \%$ o & $1 \%$ \\
\hline 1762 & 970 & $48,5 \%$ & $55,7 \%$ o & $-7,2 \%$ \\
\hline 1763 & 1002 & $57,9 \%$ & $25,9 \%$ & $32 \%$ \\
\hline 1764 & 1008 & $39,7 \%$ o & $33,7 \%$ & $6 \%$ \\
\hline 1765 & 1010 & $47,5 \%$ & $45,5 \%$ & $2 \%$ \\
\hline 1766 & 1023 & $38,1 \%$ & $25,4 \%$ & $12,7 \%$ \\
\hline 1767 & 1015 & $33,5 \%$ & $44,3 \%$ & $-10,8 \%$ \\
\hline 1768 & 1016 & $46,3 \%$ & $42,3 \%$ & $5 \%$ \\
\hline 1769 & 1026 & $31,2 \%$ & $21,4 \%$ & $9,8 \%$ \\
\hline 1770 & 1018 & $24,6 \%$ o & $16,7 \%$ & $7,9 \%$ \\
\hline 1771 & 1010 & $22,8 \%$ o & $31 \%$ & $-7,2 \%$ \\
\hline 1772 & 1013 & $22,7 \%$ & $19,7 \%$ & $3 \%$ \\
\hline 1773 & 1008 & $28,8 \%$ o & $33,7 \%$ & $-4,9 \%$ \\
\hline 1774 & 1030 & 38,8 & $17,5 \%$ & $21,3 \%$ \\
\hline Average & 17030 & $37,3 \%$ & $31,3 \%$ & $6 \%$ \\
\hline
\end{tabular}

Source: [12]

Fertility. So, according to my calculations, fertility rate for the examined period was $37,3 \%$. A little more focus on this parameter, as it appears substantially undervalued, though that figure is close to $39 \%$ inherent in Western Europe in the 1750-75 biennium [19, p. 231]. Recall that Yaresky was a small town, but its population birth rate was at the level of the number of large cities of the Commonwealth of Poland as Warsaw, Krakow and Poznan (35-38\%o). But his time Polish historian Kazimierz Gorny concluded that the fertility rate depends on the number of population in the city. For example, a relatively large city Torun in 1760 's it was $35,7 \%$, and for a small town Dalyeshytse (Daleszyce) with a population of 1109 inhabitants (just as Yaresky) $-47,9 \%$ [20, p. 280]. These trends are typical for Hetman State. Thus, the corresponding figures for the population of the largest cities of Hetman State $(41-46 \%)$ [8, p. 91] are significantly less than factor received by Yuri Voloshin for rural Staro- dub regiment in 1758-67 biennium - $60 \%$ [17, p. 129]. By this logic, the birth rate in Yaresky is closer to $50 \%$, but remember that according to the registry books, it was only $37,3 \%$. In my opinion, this is a clear demonstration of the impact on under-registered births and neonatal mortality when children were considered dead in the first days and weeks of life to their baptism. This situation is specific for all materials accounting metric in Hetman State of eighteenth century and researchers can not get around it, and require developments and correlation mechanisms to attract additional sources. But this should be the subject of separate studies, and meanwhile it seems that the "real" fertility and mortality rates were about $10 \%$ higher than those that arise as a result of our calculations.

Deaths. The overall mortality rate for Yaresky population for 1758-1774 amounted to $31,3 \%$. This is similar to the calculated by Olena Zamura for villages of Pereyaslav Regiment in 1761-1767 
- 30-39\% also on the material of metric books of Hetman State [3, p. 99]. Its value in some years has fluctuated. Minimum rate was recorded in 1770 at $16,7 \%$, the maximum was in $1762-55,7 \%$. However, fluctuations in mortality partly compensated with fluctuations in fertility, as in the most "lethal" 1762 , as the highest rate of negative natural increase $(-10,2 \%$ ) in Yaresky accounted for in 1767 , with its relatively inferior and already high mortality rate $(44,3 \%)$, which, however, did not exceed very low fertility $(33,5 \%$ ) in $10,8 \%$. Overall, in 17 years the population of the parish had the negative natural growth only 4 times, resulting in a gradual and steady increase in the number of residents of the town with a total of $6 \%$ [12].

Infant mortality, age factors.

First, I'll figure out the place of infant mortality in the mortality in general. During 1758-1774 biennium 533 persons died in the parish, among them were 294 children (0-14 years), 191 people of working age (15-15 years) and 48 elders (60 and older).

Figure 1. Age of deaths in Yaresky in 1758-1774.

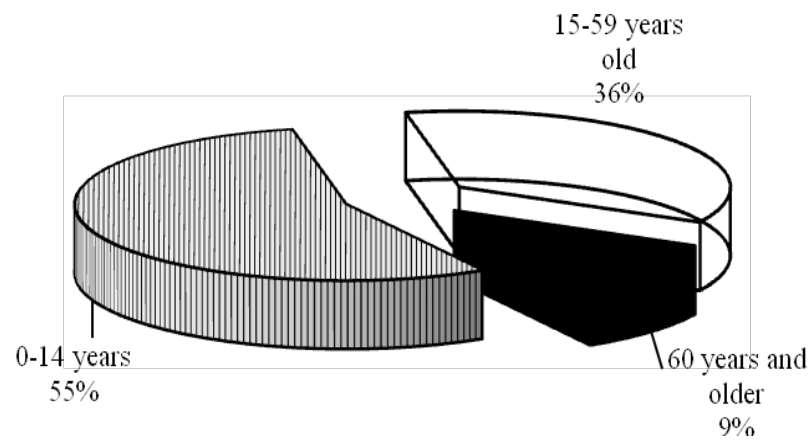

Source: [12]

As Figure 1 illustrates, the vast majority of deaths $(55,2 \%)$ in Yaresky accounted for children slightly less than that died in active age $(35,8 \%)$, after only $9 \%$ of the population died before reaching the sloping years. In general, every second funeral in the town was a child one, in this regard, our town is almost no different from neighboring towns of centesimal Sorochyntsi of Myrhorod Regiment. There, according to Olena Zamura's research, children under 14 made up of $57,4 \%$ of deaths, adults $-28,8 \%$, the elderly $-13,8 \%$ in $1741-1786$ years [21, p. 208-209]. This trend is quite characteristic for the traditional early modern society in which death was the prerogative of children and not of elders. For example, according to Polish historian Mateusz Wyżga, more than half of dead were also under 15 years in the parish of Viyentslavitse in the eighteenth century. Among 213 deaths of Catholics in Torun in 1769 with were 114 children under
14 years [4, p. 172]. A total of infant mortality in the city of reached $64 \%$, while in other years it was lower. Among all deaths among Protestants in the 1775-1789 biennium in Torun 20,8\% were children under 1 year, or $35,2 \%$ of children of five years and younger [20, p. 88]. Let's look at more secular aspects of infant mortality in Yaresky.

The least of all deaths (17 people) were in the age group of $10-14$ years, this is $5,8 \%$ of all deaths of children in Yaresky. Among them was almost the same number of boys and girls ( 8 and 9 respectively). Twice as many deaths were in the age group of 5-9 years (34 people), upon which were $11,2 \%$ of all child deaths. There were slightly more boys (19) than girls (14). After all, the vast majority of children who died $(83 \%)$ accounted in the age group of $0-4$ years. This is natural, since most deaths were just among the smallest children [12]. Almost similar rates were calculated for the population of Polish parish Viyentslavitse by Mateusz Wyżga where children under 5 years old were $79,4 \%$ of deaths [4, p. 173]. Somewhat lower was the mortality rate of children under 5 years in Lviv, which in the eighteenth century sometimes reached $60 \%$ [22, p. 175].

The ratio of deaths in the age groups of $0-4$ and 5-9 years corresponds to the so-called "paradox of infant mortality", according to which, the level of the last decreases sharply with every passing year before reaching 5 years of age. It should be noted that the effect of the paradox well manifested primarily in traditional societies with high infant mortality, and in modern time gradually leveled with the development of knowledge about newborn better care, so, for example, this paradox was finally overcome in Russia in 2002 [23].

For numerical evaluation of this phenomenon, is used so called factor of "probability of surviving to the age of five" in the historical demography. By my count, such rate for a population of Yaresky was 0,460 , that is only 460 thousand children born to survive to the age of 5 [12]. In other words, a child born in the town in the second half of the eighteenth century had a little more likely to die than become adult. A similar pattern was observed in the nearby town Sorochyntsi, where the rate of surviving to the age of five was 0,420 [21, p. 211]. Similar values were obtained by Russian scientist Boris Mironov to the territory of European Russia, where $57-58 \%$ of children did not survive to 5 years in the eighteenth century [24, p. 56].

More clearly the reduce of the number of deaths of infants under the age we see on the appropriate graph, which presents the annual death rate of children in age groups (see. Fig. 2). We see that its level 
gradually decreases to three years (37 deaths), and then stabilized in the age groups of 4-7 years at 8-12 deaths, and eventually reduced to $2-3$ deaths among children of 8-14 years. The highest mortality was in the first years of life, but its precise dimensions is impossible because of one significant drawback of the source: while recording the age of deceased, priests recorded all children a few days, weeks or months as those who turned one. Thus, by this token accumulated two-year age groups. It is significant that at the beginning of the book "about the dead", we find some records of deaths of infants under 1 or 3 months, then priest decided not too overwork and not to clear exact age, limiting the number " 1 " box age.

Figure 2. Age of children died in Yaresky in 1758-1774.

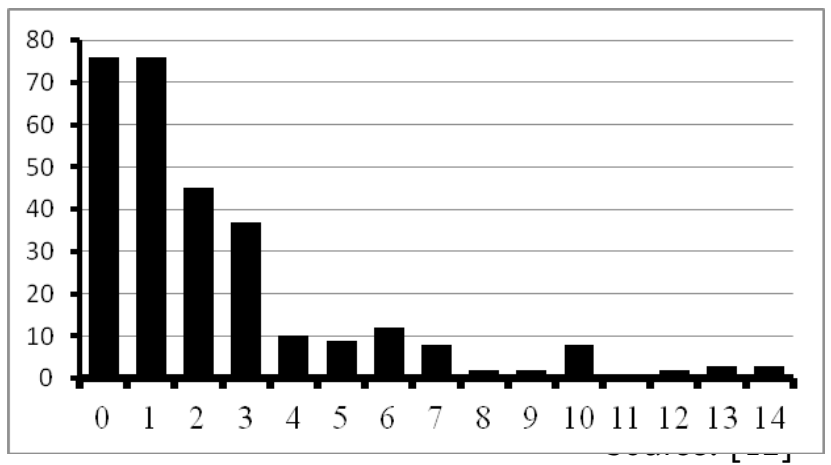

This phenomenon is universal for metrics of Hetman State in the XVIII-th century. In her time Olena Zamura solved this problem by dividing the number of one year children in half [3, p. 100]. I must admit that it does not completely remove all matters, because in terms of demographics, mortality is the highest in the first months of life. Therefore, there should be more deaths of infants under one year than of 1-year olds. For example, 11 deaths of children recorded as annuals in Yaresky in 1759, comparison of these records with the book of the baptized shows that between their baptism and death in two cases took 3 months, in one -4 months, in two -6 months, in one -8 months and in one -11 months. Thus, in fact, of the 11 children recorded as one year olds, $6-7$ did not survive to the age of one [12, p. 43-44].

For the first sight, dividing the recorded deaths of infants under one year for groups of 0 and 1 year, this problem can be solved by referring to the first part of the registry books and comparing the date of death and infant baptism. However, specifics of metric calculation in Hetman State in general and of this books in particular do not permit to make the desired accuracy. Firstly, it is not possible to establish the exact time between birth and baptism of the child. Up to now, people in Poltava region traditionally try to stick into interval of 40 days and in early modern day such traditions were stable, but the priests and congregation could adjust them as downward (in the case of fear for life) and upwards to two more months [25]. Secondly, records of the baptized and their parents were made casually, which complicates their identification. For example, daughter Martha died aged one year in the family of Kuzma Martusenko on April 24, 1762, we do not find any Kuzma Martusenko among parents in the book of baptisms, while Kuzma Shvets, who baptized daughter Martha on January 16, 1762. With high probability fate suggests that comes to the same person, but in the first case Kuzma was identified by patronymic principle, and in the second by occupation [12, ark. 5-6, 43-44]. Such cases are not rare in the book and make it impossible to give one hundred percent binding of baptism into death date, so I had to use the example of Olena Zamura (recognizing its convention).

Definitions (at least provisionally) of the number of deaths of infants under one year is required to determine the coefficient of infant mortality. To calculate it using the formula of Johannes Ratz [3, p. 100]:

$$
\mathrm{mo}=\frac{M_{o}}{\alpha \times N_{1}+\beta \times N_{-1}} \times 1000 \%
$$

where: M0 - the number of babies who died during the study year;

$\mathrm{N}-1$ - the number of births during the previous year;

$\mathrm{N} 1$ - the number of births during the current year; $\alpha+\beta=1$. According to the proposal Johannes Ratz, $\alpha=2 / 3, \beta=1 / 3$.

Substituting in this formula data from registry books of the Church of the Nativity, we will determine the rate of infant mortality in some years, and the data received is entered in the table. As you can see, its discrepancies in some years are quite substantial, from the lowest at $71,9 \%$ in 1760 to the highest $(207,3 \%$ ) in 1762 . Average value of the index ratio is $118,6 \%$. It is even less than his time Olena Zamura calculated for the population of villages of Pereyaslav Regiment (145\%o) [3, p. 100]. Surely, this is very low, so its lowest value for Western Europe in the second half of the eighteenth century was $165 \%$. As Massimo Livi Bacci stated, the traditional type of reproduction of the population difference of these factors can be up to $200 \%$ and here Bacci gives many examples how from the West and the East of Europe, particularly, from Moscow with its coefficient of $334 \%$ [26, p. 164-165]. 
Table 4. Rates of infant mortality in the 1758-1774.

\begin{tabular}{|c|c|c|c|c|c|c|c|c|}
\hline 1758 & 1759 & 1760 & 1761 & 1762 & 1763 & 1764 & 1765 & 1766 \\
\hline $115,4 \%$ & $139,9 \%$ & $71,9 \%$ & $104,2 \%$ & $207,3 \%$ & $82,7 \%$ & $87 \%$ & $132,5 \%$ & $83,3 \%$ \\
\hline 1767 & 1768 & 1769 & 1770 & 1771 & 1772 & 1773 & 1774 & $1758-74$ \\
\hline $196,1 \%$ & $140,8 \%$ & $108,1 \%$ & $109,1 \%$ & $84,7 \%$ & $108,7 \%$ & $148,1 \%$ & $96,2 \%$ & $118,6 \%$ \\
\hline
\end{tabular}

It is doubtful that infant mortality in Hetman State, which did not know professional medicine yet, was actually lower than in Central and Western Europe. Even a century later, in the Polish city of Poznan infant mortality rate was 291,9\%o [27, p. 47]. Surely, as rightly said Olena Zamura, we are dealing with a significant under-registration. It was caused by a complex influence of several factors. The first - organization of church account itself in Hetman State when only baptized children were scribed into the metric books. This combined with the established tradition of not baptize children in the first days of life. Even the Cossack elders baptized their children not earlier than the seventh day after birth, and common people did so much later (traditionally about 40 days). Delaying baptism contributed to the reluctance to pay for sending church needs of the child, who could die in the first days of life. Obviously, unbaptized children were dying so much in the population of Hetman State that in social representations they made a significant share of "residents" or hell, even there were designated place for "living" [9, p. 249-259].

All these unbaptized children passed pages of metric books and therefore in most cases left no evidence of their existence. Thus we can assume that in Yaresky (and in Hetman State general) only segment postnatal infant mortality (ages 28-days and up to one year) was recorded. Lower level of neonatal mortality rate was $91,5 \%$. in Poznan parishes in the second half of the nineteenth century. This measure of postnatal mortality correlated it as 1: 2-2.5. According to the research of Grazyna Lizhbinska the advantage of neonatal mortality was lower in the rich downtown, and increased in poor neighborhoods. Author names the factors determining this ratio as the care of health, hygiene body attitude towards breastfeeds, and the sanitary condition of the city. The last factor contributed to the fact that postnatal infant mortality rate in big cities was higher than in small towns or villages. This Polish researcher explained worse health status, and especially problems with the quality of drinking water [27, p. 46-47]. What to Yaresky in Hetman State and other settlements, the problem of safe drinking water for them was much less severe, and the burden on the environment was significantly lower, in particular through the lower population density as per unit area of the urban population. So I think that level of postnatal mortality there is lower than in Poznan of nineteenth century.

Unfortunately, Ukrainian historiography has no studies of neonatal mortality in Hetman State. Its main causes are considered congenital malformations, birth injuries, asphyxia, pneumonia, diagnosis and treatment of complications, even today $[28$, p. 273]. In early modern society such problems occurred more often, if only because labour conditions and the level of so-called "obstetrics". How consideration of this segment of infant mortality affects the calculation of the level of the Orthodox parishes should be evident in the metric books of the nineteenth century, when the requirements for accounting metric became more stringent. Such studies are not represented in Ukraine, but we can suggest as illustrative example the Russian city of Barnaul, where children of $0-4$ years accounted for $57,3 \%$ of all deaths in $1877-1886$ years, thus infant mortality was higher here than in Hetman State hundred years before. However, in this case it is more correct to speak of a better registration, rather than about different levels. Thus Pokrovsky ward stood separately with priests who most carefully kept tabs of deaths, in particular they tried to reflect as accurately as possible infant age at death, as evidenced in particular variation of this world record: "2 weeks", "7 days", "2 days" and "1 hour". Thus, children of $0-4$ years accounted for $62,4 \%$ of all deaths, thus this keeping diligence significantly "increased" levels of mortality [29].

As to the eighteenth century, this phenomenon is followed by Mateus Wyzshga in the example of the Polish parish of Viyentslavitse. He pointed out that the clergy of the parish were less carefully with the registration of deaths among his flock than the records of births and marriages. Increase of accuracy of metric books over a century was accompanied by a noticeable increase in infant mortality. In this case, too, the issue is not "real" increase in mortality, but its better fixation [4, p. 173-174]. More 
specifically, the effect of these mechanisms and its influence directly on the numerical coefficients has been recently investigated by Alysa Levene on materials of parishes in West Yorkshire in England. There one of the local priests had been trying to improve the quality of parish records since 1777 , and so historians received highly detailed parish registers [6, p. 31-42].

The significant confirms of under-registration of infant baptism is a record of twins are in the register books of Yaresky. Today the one of the biological constants is stated, according to which one couple of twins is born for every 80 births. From 1758 to 1774,636 baptisms were recorded in Yaresky so there shold be born 8 couples of twins. Instead, the register recorded only 3 , that some of these children did not live to baptism. Interestingly, baptism of two pairs of twins took place at intervals of one day: resident of Yaresky Klim Taranenko "bore Daniil and Anna" on 11, December, 1762 and resident of Yaresky Mychaeylo Dmytryk "bore Anna and Daniil" on 12 , December, $1762[12$, p. 6]. It is noticeable that the priest had many variations of names of paired saints. As for the twins, then, they were born of many women, as noted by the early eighteenth century, Ukrainian priest and poet Clement Zinoviiv $[30$, p. 110$]$, but rarely where in the world he saw adult twins. Obviously itinerant priest knew of what he wrote, because even less than in a year one of the twins Daniil (son of Michayil Dmytryk died) [12, p. 49].

\section{Annual and seasonal variations and causes of infant mortality.}

Fluctuations in mortality can give a general idea of the main factors that determine its size. The main parameters of annual fluctuations are presented in the figure. The chart shows a significant difference lowest and highest rates. So good years (1760, $1770,1772,1774) 8-9$ children aged

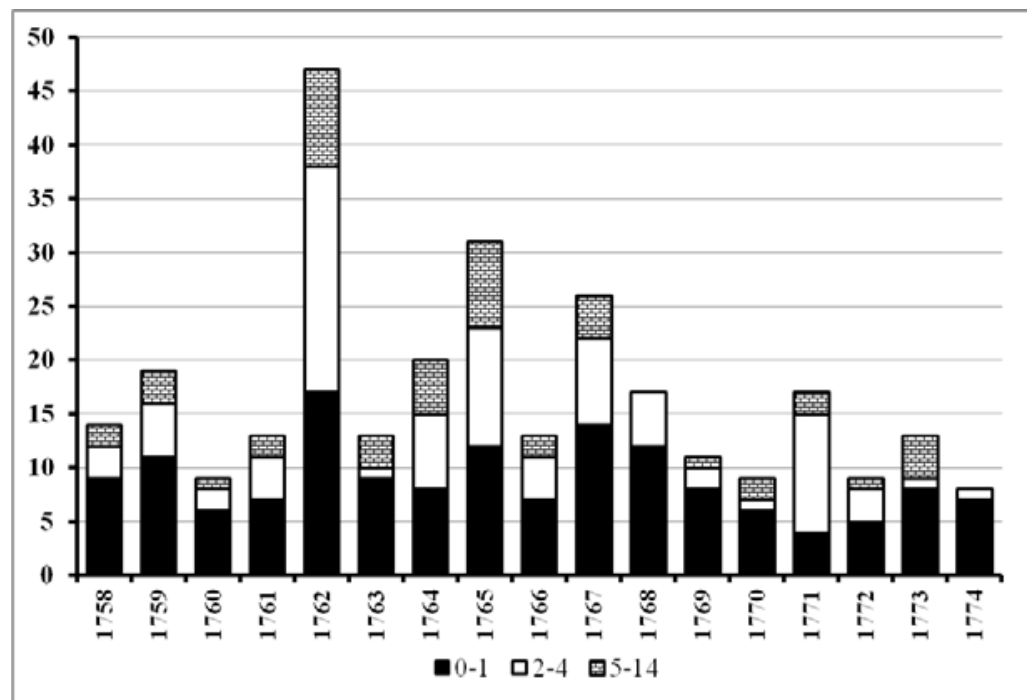

5-6 died in Yaresky under one year inclusive. Bright peaks in terms of infant mortality also were years of 1762,1765 and 1767 . The first of which is six times higher than the minimum level in 1774 .

What could be the causes of annual fluctuations in infant mortality? In some cases, the infant mortality may be related to the birth rate, it is logical that the more children are born the more they die. However, according to data of the baptism, it was not the determining factor. For example, in the crisis in 176247 babies were baptized in Yaresky and
47 children died (17 of them aged $0-1$ years). Instead, the next 1763 year, 58 babies were baptized and 13 children died ( 9 of them at the age of 90-1 year) [12, p. 47-49].

It is important that fluctuations in mortality touched children of all ages. The maximum values of 1762 and 1765 were largely achieved by jumping of kids' mortality aged 2-4 and 5-14 years. In this sense, the year 1772 is a specific one, when older children died four times greater than babies in town. This age ratio shows the influence of external factors, such as: drought, bad harvests, locust and outbreaks of epidemic diseases. For example, Ukrainian scientist Edward Ostras' found that in 6080 years of the XVIII th century Hetmanate knew only two good years -1776 and 1780 , in other years the line between malnutrition and hunger could be quite shaky. So in the 1756-1757 biennium there was a significant locust attacks which caused famine [31, p. 29]. As for the second largest infant mortality in 1765, it could be caused by a strong crop failure, recorded in sources [32]. In the following 1766 year Hetman State suffered severe drought, which caused hungry next year and also could help gather the harvest of death [31, p. 11].

Figure 3. Annual fluctuations in infant mortality in 1758-1774 Yaresky 
From this perspective, the mortality rate in 1762 differs from seasonal mortality in Yaresky in general, fluctuations of which are shown in Figure 4 [12, p. 47-48].

As we can see, the most dangerous month for children was April, it is generally for genuine for early modern days and traditionally explained with the surge of infectious diseases caused by insect vectors of their pathogens. These diseases were mainly pox and measles call, which, according to Olena Zamura, had a pronounced seasonal. Polish scholar Malgorzata Zmiyevska explains a similar situation in the parish of Serny in the Commonwealth of Poland with these same factors [3, p. 91]. But do not forget that by April the stocks of food and malnutrition had had to end, and deterioration in the quality of food intake and depletion weakened body resistance. In particular this applies to children who were not breastfed. On the other hand, hunger weakened mothers who had to give birth at that time.

Figure 4. Seasonal variations in infant
mortality Yaresky in 1758-1774 years.

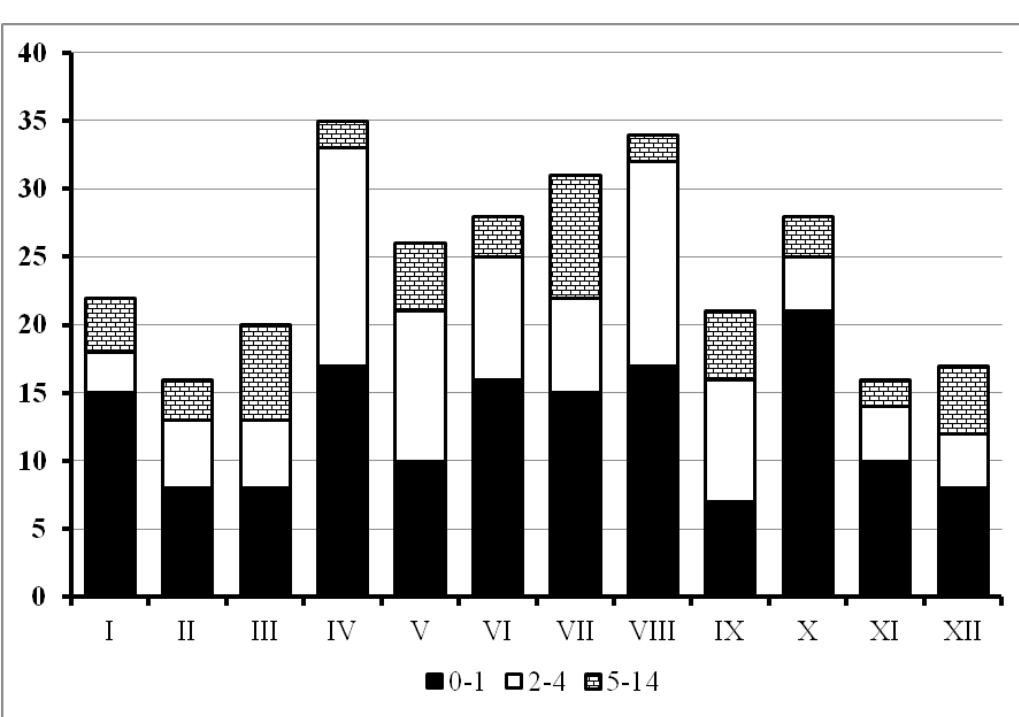
p. 36-37].

however, it rained a lot in July. But August was drier, reinforcing the effect of heat, including its impact on her deteriorating water quality and sanitation in villages of Hetman State. For example, even today one of the largest rivers Hetman State of that time are very shallow in August and the water is becoming musty, covered by a film of small green algae. But this is only one aspect. Health, well-being, and hence mortality of person depends on many factors, including weather events, including the first place - fluctuations in temperature and pressure [33,

Let us not forget that in the warmer months, children are often left without by parents' control who had to work outside the home. Duties of care were put on older young children or the elderly, who could not perform them very carefully. And because young children failed to receive food or water, and older ones died from accidents. Just with eloquent record of 22 May, 1725 on a case begins known to all researchers diary of Hetman Petro Apostol: "2-years old boy in Suhovtsi, fell into the pit with water where lime was slaked, drowned." [34, p. 105].

I'll note that Polish historians were similar in picturing seasonality of infant mortality. For example, the population of the Polish city $\mathrm{K}$ pno in eighteenth century also met summer maximums, which was explained by the researchers with infections and work of relatives in the fields, and, consequently, with the worst child care [35, p. 74].

Yaresky infant mortality rate declined sharply in September to bounce back in October. This month is unique in terms of age departed: for then died least older children. Sanitary situation improved in October, but it was the

Source: [12]

However, the availability of food was not a panacea, and in hearty summer months, infant mortality is rising again from June to August. This month is the second in its level in Yaresky. Warm season traditionally contributed to the break-up of digestive tract diseases, food poisoning and intestinal infections. Indirect evidence of this we find in our source when several children died in one family. For example, on 20, July, 1755 Yaresky layman's Yarema Kalchenko 1-year old son Ioan died and on 24, July his two-year old daughter Paraskeva died, too [21, p. 42]. Significantly, the peak of mortality in warm season is accounted for on a hot August. It should be noted that the hottest in these areas was July, time of the first frost, which in turn contributed to colds. Cold or some other plague could be brought by child from outside and it could infect others. Maybe it happened in the family of Tymish Tkach. On 14, October, 1762 his daughter Matrona died (3 years), and on 1, November, 1762 - hid son Fedir (1 year) $[12$, p. 42, 48]. The source captures most of these cases in autumn, but there happened at other times of the year. For example, on March, 8, 1767 resident of Yaresky Carp Shvydkyi's son Antoniy died aged 1 year and two weeks later (March 31) - his six-years old son Vasyl [12, p. 53]. It is likely that we are dealing with infections, and it's a pitty that source does not specify the cause of death, but the story can be studied in detail, for example, of 
the interval between these deaths. It is preferably 2 weeks. It is important that these infections threatened the lives of adults, too. For example, on 17, April, 1755 in Mykyta Pivovarenko's family 1-year old son Zachariah died, and on May 7, - his wife Yevdokiya [12, p. 42].

\section{Conclusions}

The study of infant mortality in the parish church of the Nativity highlighted are essential features of Orthodox metric books of early modern Ukraine, which will cause many more problems to Ukrainian demography historians. Their roots are in that fact that by the end of the eighteenth century the secular and religious authorities of the empire were not too successful in disciplining Orthodox priests, at least not enough to get them to be careful to keep records of social condition of the population of the parish. Due to the low level of education and the irresponsible attitude of the priests, books were full of errors, inaccuracies in the sense of specifying names, ages, dates, etc. But most importantly, there is no specified date of birth of the child, and only a mention of its baptism, respectively only baptized accounted for death, and notes didn't indicate the reason.

Under-registration of dead children was traced on the materials of Central and Western Europe of the XVIIIth century, but to a lesser extent. Instead not-baptized dead children omitted pages of the metric book of the Church of the Nativity. Thus in Yaresky (and in Hetman State in general) only postnatal infant mortality segment (ages 28-days and up to one year) was recorded, and neonatal mortality was hardly taken into account. The ideal solution to this problem would be finding precisions of metric books that seems unlikely for Hetman State. So, we will calculate the corresponding correlation coefficients on the materials of the nineteenth century, when the quality of accounting population hasd grown, but the mortality rate of children had not changed significantly because of the almost complete absence of qualified medical support.

As for children, they accounted for more than half of all deaths of Yaresky residents that was generally typical for early modern Europe. The age distribution of deaths of infants corresponds to the so-called "paradox of infant mortality", according to which, the last level decreases sharply with every passing year before reaching 5 years of age. However, only 460 thousand children born in Yaresky survived to 5 years of age. In other words, a child born in the town in the second half of the eighteenth century, had a little more likely to die than to become an adult. The highest mortality was in the first years of life, but its precise dimensions is impossible because of one significant drawback of the source: priests recorded all children of a few days, weeks or months of age as those who turned one while recording the age of deceased. Thus, by this token accumulated two-year age groups. This, along with an underestimation, prevents accurate computation of the infants, and received data is comparable except that to similar to the Hetmanate, but far from Western-European.

In terms of seasonal variations, the most dangerous for children month was April, it was generally for genuine early modern days and traditionally explained by the surge of infectious diseases. They also had to meet the lack of stocks of food that caused malnutrition and weaken the resistance of the body. Particularly this applies to children who were not breastfed. On the other hand, hunger weakened mothers who had to give birth at that time. In the summer months, nutritious infant mortality is rising again from June to August. This month it is the second in the level in Yaresky. Warm season traditionally contributed digestive tract diseases, food poisoning, intestinal infections. Researchers tend to explain August peak of mortality more with employment of relatives in field work and, consequently, with the worst child care. Of course, these are not all of the important causes of jumps of mortality, their definition requires some research and broader empirical data for comparisons and generalizations that for the society of Hetmana State.

\section{Sources and literature}

1. Арьес Ф. Человек перед лицом смерти / Пер. с фр., ред. Оболенской С.; предисл. Гуревича А. Москва: Издательская группа «Прогресс», 1992. 528 с.

2. Vovelle M. Śmierć w cywilizacji Zachodu od roku 1300 po współczesność. Gdańsk, 2008. 856 s.

3. Замура 0. «Великий шаленець»: смерть і смертність в Гетьманщині XVIII ст. Київ: К.I.С., 2014. 240 с.

4. Wyżga M. Śmierć dziecka w rodzinie chłopskiej w XVIII-wiecznej parafii Więcławice koło Krakowa. W kręgu rodyiny epok dawnych. Dzieciństwo. Warszawa, 2014. S. 161-185.

5. Chamoux A. Town and Child in eighteenth century Rheims. Local population studies. 1974. №12. P.45-46.

6. Levene A. What can Dade registers tell us about infant mortality in the later eighteenth century. Local population studies. 2006. №76, P.31-42 
7. Kukło C. Demografija Rzeczypospolitej przedrozbiorowej. Warszawa, 2009. 534 s.

8. Сердюк I. Полкових городов обивателі: історико-демографічна характеристика міського населення Гетьманщини другої половини XVIII ст. Полтава: ТОВ «АCMI», 2011. 304 с.

9. Сердюк I. Маленький дорослий: Дитина й дитинство в Гетьманщині XVIII ст. Київ: КIC, 2018. 456 с.

10. Serdiuk I. Childhood and age limits in society of Getmanat XVIII century. Bylye gody. 2015. №3. C. 499-507.

11. Сердюк И. Эмоциональная составляющая убийства «нечистого» ребенка (эпизод из жизни Гетманщины XVIII

в.). Антропологический форум. 2015. № 25. С. 118-144.

12. Державний архів Полтавської області (далі - ДАП0). Ф.1011. 0п.1. Спр. 157.

13. Дмитренко В. Матеріали церковного обліку населення Київської та Переяславсько-Бориспільської єпархій як джерело вивчення соціуму Гетьманщини XVIII століття. Полтава: Сімон, 2016. 198 с.

14. Shryock H. S., Siegel J.S. Methods and Materials of Demography. New York, 1976. 577 p.

15. Волошин Ю. Статево-вікова структура населення міста Полтави в другій половині XVIII ст. Історична пам'ять. 2011. № 1. С. 5-24.

16. Муромцева Ю. Демографія: Навчальний посібник. К.: Кондор, 2006. 300 с.

17. Волошин Ю. Розкольницькі слободи на території Північної Гетьманщини у XVIII ст. (історико-демографічний аспект). Полтава: ACMI, 2005. 312 с.

18. Описи Київського намісництва 70-80 років XVIII ст.: описово-статистичні джерела. Київ, 1989.

19. Урланис Б. Рост населения в Европе (опыт исчисления). Москва: Госполитиздат, 1941. 436 с.

20. Górny K. Ze studiów nad stosunkami ludnościowymi Torunia w XVIII w. Acta Universitatis Nicolai Copernici. Nauki Humanistyczno-Społeczne. Toruń, 1977. Historia. XI. Tom 11 (74). S. 71-97.

21. Замура 0. Смертність в природному русі населення містечка Сорочинці і XVIII ст. (за даними метричних книг Миколаївської церкви). Краєзнавство. 2009. № 3. С. 207-213.

22. Капраль М. Національні громади Львова XVI-XVIII ст. (соціально-правові взаємини). Львів: ЛнУ ім. І. Франка, Львівське відділення Ін-ту української археографії та джерелознавства ім. М. С. Грушевського НАН України, 2003. 440 c.

23. Кваша М., Кхаркова Т. Смертность младенцев в России: успехи и нерешенные проблеммы. Демоскоп. [Електронний ресурс]. Режим доступу: С. 461-462. http://demoscope.ru/weekly/2011/0461/analit04.php

24. Миронов Б. Русский город в 1740-1860-е годы: Демографическое, социальное и экономическое развитие.

Ленинград: Наука, 1990. 272 с.

25. Дьячков В. Л., Кончаков Р. Б., Канищев В. В. Декабрьские рождения. К вопросу о роли религиозного фактора в демографическом поведении традиционного крестьянства. Тамбовская губерния, XIX - начало XX в. Родословное древо: Тезисы и мат.: Город Тамбов в прошлом, настоящем и будущем: Социально-демографическая история России XIX-XX вв. [Електронний ресурс]. Режим доступу: https://goo.gl/7oGDMm.

26. Баччи М. Демографическая история Европы / Пер. с итал. А. Миролюбовой. СПб.: Александрия, 2010. 304 с.

27. Licybińska G. Umieralność $i$ jej uwarunkowania wśród katolickiej i ewangelickiej ludności historycznego

Poznania. Poznań, 2009. 210 s.

28. Демографический энциклопедический словарь. Москва: 1985. 608 с.

29. Сарафанов Д., Спесивцева М. Некоторые аспекты изучения смертности населения Барнаула во второй половине XIX в. (по материалам базы данных «Население Барнаула»). Этнодемографические процессы в Казахстане и сопредельных территориях: Сборник научных трудов X Международной научно-практической конференции. 15-16 мая 2009 г., Усть-Каменогорск. Усть-Каменогорск: «Либриус», 2009. С. 328-336.

30. Зіновіїв К. Вірші. Приповісті посполиті. Київ: Наукова думка, 1971. 392 с.

31. Острась Е. Врожайність зернових культур, хлібні ціни та забезпеченість населення хлібом в Лівобережній Україні в другій половині XVIII ст. Донецьк: Донецький національний університет, 2003. 80 с.

32. А. А. [Андриевский А.] Вздорожание хлеба в Киеве в 1765 г. Киевская старина. 1891. № 12. С. 474-476.

33. Wnęk K. Metodz badania korelacji sezonowości zgonów ze yjawiskami klimatzcynzmi. Przeszłość Demograficzna Polski. 1997. №20. S.36-47.

34. Дневник Петра Даниловича Апостола (май 1725 г. - май 1727 г.). Киевская старина. 1895. № 7-8. С. 100155.

35. Stępińska M., Rzemieniecki A. Ludność katolicka i ewangelicka Kępna w wieku. Przeszłość Demograficzna Polski". 2011. № 30. S. 53-77. 